\title{
DILEMA DISKRESI BAGI PEJABAT PEMERINTAHAN
}

\author{
Dian Eka Rahayu Sawitri
}

Lembaga Administrasi Negara

\begin{abstract}
Asbtrak
Diskresi dalam Undang-Undang Nomor 30 Tahun 2014 tentang Administrasi Pemerintahan (UU AP) didefinisikan sebagai keputusan dan/atau tindakan yang ditetapkan dan/atau dilakukan oleh Pejabat Pemerintahan untuk mengatasi persoalan konkret yang dihadapi dalam penyelenggaraan pemerintahan dalam hal peraturan perundang-undangan yang memberikan pilihan, tidak mengatur, tidak lengkap atau tidak jelas, dan/atau adanya stagnasi pemerintahan. UU AP mengatur Diskresi secara rigid sehingga sampai saat ini masih terjadi kegamangan di kalangan pejabat pemerintah untuk melakukan diskresi. Padahal sesungguhnya penggunaan diskresi dapat mengakselerasi pembangunan dan pelayanan publik. Agar tidak terjadi dilema dalam melaksanakan diskresi maka operasionalisasi diskresi perlu diatur lebih lanjut dalam Peraturan Pemerintah yang bersifat mandiri. Selain itu penggunaan diskresi harus diimbangi dengan jaminan kepastian hukum bagi pejabat pemerintahan.
\end{abstract}

Kata kunci: diskresi, pejabat pemerintahan, pelayanan publik

\begin{abstract}
Based on Law Number 30 of 2014 concerning Government Administration, discretion is defined as a decision and/or action determined and/or performed by public administrator to address problems in the administration of government in the case of laws that provide choice, do not regulate, are incomplete or unclear, and/or in the case of government stagnation. Government Administration Law regulates discretion rigidly so that until now government officials tend to be reluctant in exercizing discretion, despite utilizing discretion can help government officials to accelerate development and public service. Therefore, the operationalization of the discretion needs to be further regulated in a Government Regulation. Furthermore, the exercise of discretion must be balanced with the legal certainty for government officials.
\end{abstract}

Keywords: discretion, public administrator, public service

\section{Pendahuluan}

Diberlakukannya UndangUndang Nomor 30 Tahun 2014 tentang Administrasi Pemerintahan (UU AP) sejak tanggal 17 Oktober 2014, menjadi tonggak sejarah baru bagi reformasi administrasi di Indonesia. Pejabat pemerintahan yang berwenang diberi peluang untuk melakukan diskresi (membuat keputusan dan/atau tindakan untuk mengatasi persoalan konkret yang

18 Indonesia, Undang-Undang Administrasi Pemerintahan, UU No.30 Tahun 2014, LN No. dihadapi dalam penyelenggaraan pemerintahan) dengan tujuan untuk $:^{18}$

1. melancarkan penyelenggaraan pemerintahan;

2. mengisi kekosongan hukum;

3. memberikan kepastian hukum;

4. mengatasi stagnasi pemerintahan dalam keadaan tertentu guna kemanfaatan dan kepentingan umum. 
Dengan demikian UU AP merupakan dasar hukum bagi Badan dan/atau Pejabat Pemerintah, warga masyarakat dan pihak-pihak lain yang terkait dengan Administrasi Pemerintahan dalam upaya meningkatkan kualitas penyelenggaraan pemerintahan. ${ }^{19}$

Namun sayangnya hingga saat ini masih banyak Pejabat Pemerintah yang ragu untuk menggunakan diskresi ketika menghadapi persoalan dalam penyelenggaraan pemerintahan. Sebagian besar aparatur pemerintahan khawatir jika melakukan diskresi maka keputusan dan/atau tindakan tersebut kemudian hari dimaknai sebagai penyimpangan administrasi (maladministrasi) yang menjadi cikal bakal tindak pidana umum maupun tindak pidana korupsi. Berdasarkan hal tersebut maka upaya apa yang dapat dilakukan agar pejabat pemerintahan tidak ragu ataupun takut untuk melaksanakan diskresi demi meningkatkan pembangunan dan pelayanan publik?

\section{Konsep Diskresi}

Menurut para ahli, diskresi ini muncul karena adanya perkembangan masyarakat yang berdampak pada terjadinya keadaan-keadaan tertentu yang sifatnya mendesak yang membuat pejabat pemerintah tidak dapat menggunakan kewenangannya khususnya yang bersifat terikat (gebonden bevoegheid) dalam melaksanakan

\footnotetext{
19 Ibid, Ps. 2.

20 Julista Mustamu, Diskresi dan Tanggungjawab Administrasi Pemerintahan, SASI (April-Juni 2011):1.

21 Marcus Lukman sebagaimana dikutip oleh Saut P. Panjaitan, Eksistensi Peraturan Kebijaksanaan dalam Bidang Perencanan dan Pelaksanaan Rencana Pembangunan di Daerah serta Dampaknya Terhadap Pembangunan Materi Hukum Tertulis Nasional, dalam S.F. Marbun, Pembentukan, Pemberlakuan, dan Peranan Asas-asas Umum Pemerintahan yang Layak dalam Menjelmakan Pemerintahan yang
}

tindakan hukum dan tindakan faktual secara normal. ${ }^{20}$ Markus Lukman berpendapat bahwa, diskresi (pouvoir discretionnaire, Perancis) ataupun Freies Ermessen (Jerman) merupakan suatu bentuk penyimpangan terhadap asas legalitas dalam pengertian wet matigheid van bestuur, jadi merupakan "kekecualian" dari asas legalitas. ${ }^{21}$

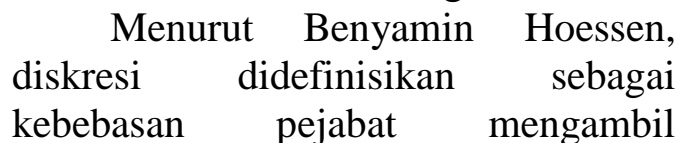
keputusan menurut pertimbangannya sendiri. $^{22}$ Dengan demikian, menurutnya setiap pejabat publik memiliki kewenangan diskresi. Selanjutnya Gayus T. Lumbuun mendefinisikan diskresi sebagai kebijakan dari pejabat negara dari pusat sampai daerah yang intinya membolehkan pejabat publik melakukan sebuah kebijakan yang melanggar dengan undang-undang, dengan tiga syarat, yaitu demi kepentingan umum, masih dalam batas wilayah kewenangannya, dan tidak melanggar Asas-asas Umum Pemerintahan yang Baik (AUPB). ${ }^{23}$

Sedangkan definisi diskresi menurut Sjachran Basah seperti dikutip oleh Patuan Sinaga, adalah : ${ }^{24}$

"..., tujuan kehidupan bernegara yang harus dicapai..., melibatkan administrasi negara di dalam melaksanakan tugas-tugas servis publiknya yang sangat kompleks, luas lingkupnya, dan memasuki semua sektor kehidupan. Dalam hal

Baik dan Bersih di Indonesia, (Disertasi Doktor Universitas Padjadjaran, Bandung, 2001), hlm. 17.

${ }^{22}$ Benyamin Hoessen, Pembagian Kewenangan Antara Pusat dan Daerah (Arena Hukum : Nomor 13, Februari 2011).

23 Gayus T. Lumbuun, Pro Kontra Rencana Pembuatan Peraturan untuk Melindungi Pejabat Publik, http://www.hukumonline.com, diunduh tanggal 16 maret 2008

24 Sjachran Basah, Perlindungan Hukum Terhadap Sikap Tindak Administrasi Negara, (Bandung : Alumni, 1997). 
administrasi negara memiliki keleluasaan dalam menentukan kebijakan-kebijakan walaupun demikian sikap tindaknya itu haruslah dapat dipertanggungjawabkan baik secara moral maupun hukum".

Berdasarkan definisi yang diberikan oleh Syachran Basah tersebut, tersimpulkan bahwa unsur-unsur yang harus dipenuhi oleh suatu diskresi adalah sebagai berikut $:^{25}$

1. Ada karena adanya tugas-tugas public service yang diemban oleh administratur negara;

2. Dalam menjalankan tugas tersebut, para administratur negara diberikan keleluasaan dalam menentukan kebijakan-kebijakan;

3. Kebijakan-kebijakan tersebut dapat dipertanggungjawabkan baik secara moral maupun hukum.

\section{S. Prajudi Atmosudirjo} menjelaskan bahwa diskresi diperlukan sebagai pelengkap dari asas legalitas, yaitu asas hukum yang menyatakan bahwa setiap tindakan hukum atau perbuatan administrasi negara harus berdasarkan ketentuan UU. Namun dalam praktiknya, karena tidak mungkin bagi UU untuk mengatur segala hal dalam praktik kehidupan sehari-hari maka diperlukan adanya diskresi. ${ }^{26}$ Diskresi menurut Prajudi ada dua, yaitu diskresi bebas dan diskresi terikat. ${ }^{27}$ Pada diskresi bebas, UU hanya menetapkan batas-batas dan pengambil kebijakan bebas mengambil keputusan apa saja asalkan tidak melampaui/melanggar batas-batas tersebut. Sedangkan pada diskresi terikat, UU menetapkan beberapa alternatif keputusan dan pengambil kebijakan bebas memilih salah satu

\footnotetext{
${ }^{25}$ Ibid

${ }^{26}$ S. Prajudi Atmosudirdjo, Hukum Administrasi Negara, (Jakarta: Ghalia Indonesia, 1995), hlm. 82.
}

alternatif keputusan yang disediakan UU tersebut.

Dalam Undang-Undang Administrasi Pemerintahan diskresi didefinisikan sebagai "Wewenang Badan atau Pejabat Pemerintahan yang memungkinkan untuk melakukan pilihan dalam mengambil tindakan hukum dan/atau tindakan faktual dalam administrasi pemerintahan." ${ }^{28}$ Beberapa syarat diskresi adalah sebagai berikut: ${ }^{29}$

1. Sesuai dengan tujuan diskresi;

2. Tidak bertentangan dengan ketentuan peraturan perundangundangan;

3. Sesuai dengan AUPB;

4. Berdasarkan alasan-alasan yang objektif. Yang dimaksud dengan "alasan-alasan objektif" adalah alasan-alasan yang diambil berdasarkan fakta dan kondisi faktual, tidak memihak, dan rasional serta berdasarkan AUPB;

5. Tidak menimbulkan konflik kepentingan; dan

6. Dilakukan dengan iktikad baik. Yang dimaksud dengan "iktikad baik" adalah keputusan dan/atau tindakan yang ditetapkan dan/atau dilakukan didasarkan atas motif kejujuran dan berdasarkan AUPB.

\section{Diskresi Prosedural}

Diskresi muncul karena adanya tujuan kehidupan bernegara yang harus dicapai, tujuan bernegara dari faham negara kesejahteraan adalah untuk menciptakan kesejahteraan rakyat. Untuk mencapai tujuan bernegara tersebut maka pemerintah berkewajiban memperhatikan dan memaksimalkan upaya keamanan sosial dalam arti seluas-luasnya. Hal tersebut mengakibatkan pemerintah harus aktif

\footnotetext{
${ }^{27}$ Ibid.

${ }^{28}$ Indonesia, Undang-undang tentang Administrasi Pemerintahan, Pasal. 1 angka 5.

${ }^{29}$ Ibid. Pasal 24.
} 
berperan mencampuri bidang kehidupan sosial-ekonomi masyarakat (public service) yang mengakibatkan administrasi negara tidak boleh menolak untuk mengambil keputusan ataupun bertindak dengan dalih ketiadaan peraturan perundangundangan (rechtsvacuum).

Pelaksanaan penyelenggaraan pemerintahan, membawa konsekuensi adanya hak kebebasan bagi administratur negara (mencakup aparatur dan lembaga di dalamnya) untuk bertindak atas inisatif sendiri (freies ermessen/ diskresionare) dalam batas kewenangan yang dimilikinya. Istilah ini kemudian secara khas digunakan dalam bidang pemerintahan, sehingga freies ermessen/diskresionare dapat diartikan sebagai salah satu sarana yang memberikan ruang gerak bagi Pejabat atau Badan Administrasi Negara untuk melakukan tindakan tanpa harus terikat sepenuhnya pada peraturan perundangundangan.

Secara konsepsional, implementasi freies ermessen/diskresionare lebih mengutamakan keefektifan tercapainya suatu tujuan (doelmatigheid) daripada sekedar mematuhi sepenuhnya ketentuan hukum (rechtmatigheid). Hal ini tidak terlepas dari dinamika kebutuhan masyarakat yang begitu cepat, yang seringkali tidak terprediksi dari awal (unpredictable) atau bahkan tidak terjangkau oleh prosedur formal yang diatur dalam berbagai kebijakan. Terlebih, saat ini, aparatur pemerintahan dituntut dan berlomba-lomba melakukan inovasi untuk mengakselerasi pembangunan dan pelayanan publik.

Semangat pembentukan UU AP sebenarnya mengatur agar penyelenggara pemerintahan mempunyai rambu-rambu yang jelas dalam melaksanakan keputusan maupun tindakan pemerintahan dan menghindari penya- lahgunaaan wewenang aparatur pemerintah. Diskresi yang diatur dalam UU AP, merupakan diskresi bersyarat dan mekanistis (prosedural).

Mengenai lingkup diskresi, dalam UU AP dijelaskan bahwa Diskresi Pejabat Pemerintahan meliputi: ${ }^{30}$

1. Pengambilan keputusan dan/atau tindakan berdasarkan ketentuan peraturan perundang-undangan yang memberikan suatu pilihan keputusan dan/atau tindakan. Pilihan keputusan dan/atau tindakan Pejabat Pemerintahan dicirikan dengan kata dapat, boleh, atau diberikan kewenangan, berhak, seharusnya, diharapkan, dan kata-kata lain yang sejenis dalam ketentuan peraturan perundang-undangan. Sedangkan yang dimaksud pilihan keputusan dan/atau tindakan adalah respon atau sikap Pejabat Pemerintahan dalam melaksanakan atau tidak melaksanakan Administrasi Pemerintahan sesuai dengan ketentuan peraturan perundangundangan.

2. Pengambilan keputusan dan/atau tindakan karena peraturan perundang-undangan tidak mengatur. Yang dimaksud dengan "peraturan perundang-undangan tidak mengatur" adalah ketiadaan atau kekosongan hukum yang mengatur penyelenggaraan pemerintahan dalam suatu kondisi tertentu atau di luar kelaziman.

3. Pengambilan keputusan dan/atau tindakan karena peraturan perundang-undangan tidak lengkap atau tidak jelas. Yang dimaksud dengan "peraturan perundangundangan tidak lengkap atau tidak jelas" apabila dalam peraturan perundang-undangan masih membutuhkan penjelasan lebih lanjut, peraturan yang tumpang tindih (tidak harmonis dan tidak

${ }^{30}$ Ibid. Pasal 23. 
sinkron), dan peraturan yang membutuhkan peraturan pelaksanaan, tetapi belum dibuat.

4. Pengambilan keputusan dan/atau tindakan karena adanya stagnasi pemerintahan guna kepentingan yang lebih luas. Yang dimaksud dengan "kepentingan yang lebih luas" adalah kepentingan yang menyangkut hajat hidup orang banyak, penyelamatan kemanusiaan dan keutuhan negara, antara lain: bencana alam, wabah penyakit, konflik sosial, kerusuhan, pertahanan dan kesatuan bangsa.

\begin{tabular}{|l|l|l|}
\hline $\begin{array}{l}\text { PUU memberi opsi } \\
\text { keputusan/tindakan }\end{array}$ & \\
\cline { 1 - 2 } $\begin{array}{l}\text { PUU tidak mengatur } \\
\text { keputusan/tindakan }\end{array}$ & \\
\hline $\begin{array}{l}\text { PUU tidak } \\
\text { lengkap/tidak jelas }\end{array}$ & & \\
\hline $\begin{array}{l}\text { Ada stagnasi } \\
\text { pemerintahan }\end{array}$ & & \\
\hline
\end{tabular}

Selain itu diskresi juga harus memenuhi banyak syarat yaitu untuk mengatasi persoalan kongkret, peraturan perundang-undangan yang memberikan pilihan, tidak mengatur, tidak lengkap atau tidak jelas, dan/atau adanya stagnasi pemerintahan. Masih ada lagi syarat harus ada itikad baik, tidak boleh bertentangan dengan peraturan perundang-undangan dan tidak menimbulkan konflik kepentingan.

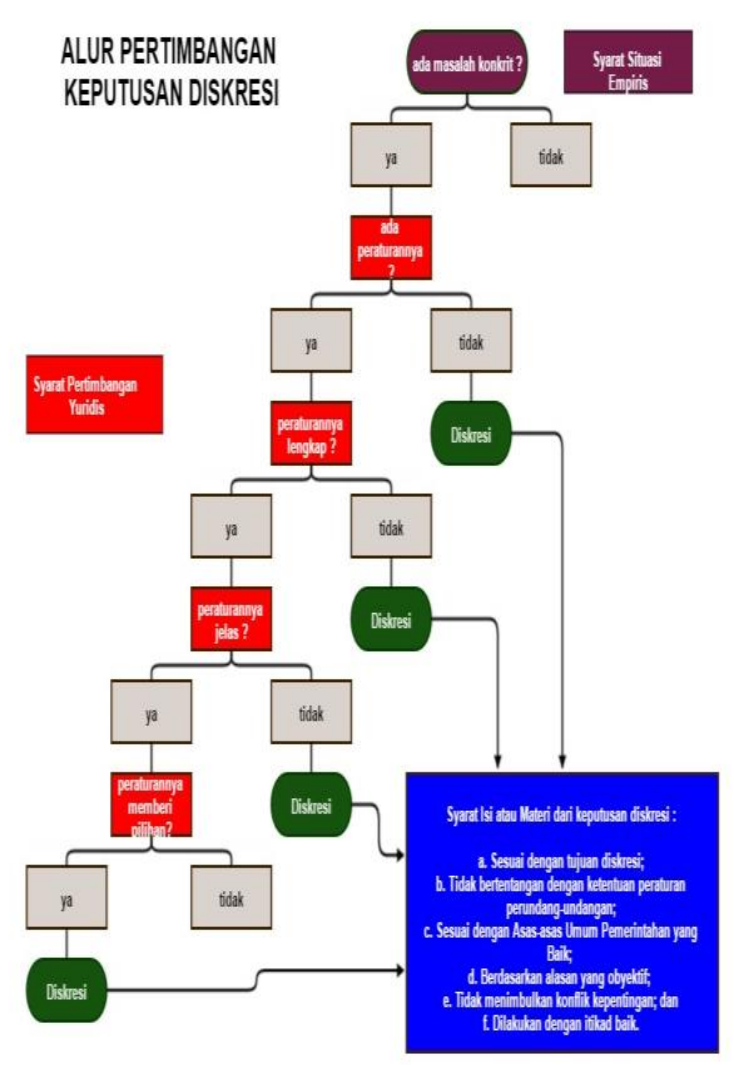

Selain itu, secara mekanisme, diskresi harus dilaporkan dan meminta persetujuan atasan terlebih dahulu apabila diksresi yang akan diambil berkaitan dengan alokasi anggaran. Sedangkan apabila diskresi akan menimbulkan keresahan masyarakat, keadaan darurat, mendesak dan/atau terjadi bencana alam, Pejabat Pemerintahan wajib memberitahukan kepada Atasan Pejabat sebelum penggunaan diskresi dan melaporkan kepada Atasan Pejabat setelah penggunaan Diskresi. Bahkan, dalam UU AP disebutkan mekanisme pengajuan permohonan maupun penyampaian laporan diskresi dalam batas waktu 5 (lima) hari, baik sebelum atau sesudah diskresi dilakukan. Artinya, diskresi berdasarkan UU AP sulit untuk dilaksanakan dan bukan sebagaimana diskresi yang ideal. 
Prosedur terkait tindakan diskresi, dalam UU AP dijelaskan sebagai berikut : 31

1. Dalam hal penggunaan diskresi yang berpotensi mengubah alokasi anggaran serta menimbulkan akibat hukum yang berpotensi membebani keuangan negara, wajib memperoleh persetujuan dari Atasan Pejabat.

2. Dalam hal penggunaan diskresi yang berpotensi menimbulkan keresahan masyarakat, Pejabat Pemerintahan wajib melaporkan kepada Atasan Pejabat sebelum penggunaan diskresi tersebut.

3. Penggunaan Diskresi dalam keadaan darurat, mendesak dan/atau terjadi bencana alam, Pejabat Pemerintahan wajib memberitahukan kepada Atasan Pejabat setelah penggunaan diskresi.

Penggunaan diskresi yang berpotensi mengubah alokasi anggaran serta menimbulkan akibat hukum yang berpotensi membebani keuangan negara, wajib memperoleh persetujuan dari Atasan Pejabat. Prosedur tersebut akhirnya menyebabkan banyak pejabat yang menolak untuk melaksanakan diskresi, terutama jika diskresi yang akan diambil berdampak pada keuangan negara. Diskresi yang dilakukan akan dianggap sebagai bentuk penyalahgunaan wewenang dan bisa mengarah kepada tindak pidana korupsi, bahkan ada sebagian kalangan APH yang berpendapat bahwa UU AP ini tidak mendukung semangat antikorupsi.

UU AP sebenarnya berusaha memperjelas diskresi dan penggunaannya yang merupakan suatu pilihan bahwa itu bukanlah kebebasan yang sebebas-bebasnya. Namun yang terjadi justru mengakibatkan diskresi tersebut bersifat prosedural.

\footnotetext{
${ }^{31}$ Ibid. Pasal 25.

${ }^{32} \mathrm{http} / / /$ setkab.go.id/bertemu-1768-pejabat-
}

\section{Penutup}

Penggunaan diskresi untuk meningkatkan pembangunan dan pelayanan publik sudah seharusnya didukung. Hal ini sesuai dengan pidato Presiden pada tanggal 24 Agustus 2015 di Istana Bogor yang menyatakan bahwa :

1. Kebijakan tidak dipidana dan kesalahan administrasi cukup ditangani oleh APIP sesuai UU AP;

2. Tindakan administrasi pemerintahan terbuka juga dilakukan tuntutan secara perdata, tidak harus dipidanakan, sehingga hanya cukup melakukan pengembalian;

3. Aparat dalam melihat kerugian negara harus konkret bahwa benarbenar atas niat untuk mencuri;

4. Badan Pemeriksa Keuangan (BPK) dan Badan Pengawasan Keuangan dan Pembangunan (BPKP) jika melihat ada indikasi kesalahan administrasi keuangan negara, diberi waktu 60 (enam puluh) hari untuk perbaikan. Dalam masa perbaikan tersebut, Aparat Kepolisian, Kejaksaan, dan APH tidak boleh intervensi; dan

5. Tidak boleh melakukan ekspose tersangka sebelum dilakukan penuntutan.

Selain itu dalam Rapat Kerja Pemerintah di bulan Juni 2016, Presiden juga menyatakan bahwa kita harus mengubah orientasi dari prosedur menjadi hasil. ${ }^{32}$

Pejabat Pemerintah diberikan kewenangan untuk melakukan diskresi sebagai bentuk tindakan pemerintahan yang bersifat quick response dan lebih dilihat dari aspek pemenuhan kepentingan masyarakat dibandingkan dengan ketaatan prosedur semata. Dengan mengingat prinsip hukum pidana yang bersifat ultimum remedium, bukan primum remedium atau bahkan

eselon-ii-presiden-jokowi-kalau-usul-anggaranngga-usah-banyak-banyak/ 
maximum remedium, yakni "hukum pidana hendaknya menjadi sarana terakhir yang digunakan untuk mencapai tujuan hukum' maka keraguan untuk melaksanakan diskresi dapat ditepis.

Rekomendasi stratejik yang ditawarkan untuk mengatasi permasalahan tersebut adalah sebagai berikut:

1. Operasionalisasi diskresi perlu diatur lebih lanjut dalam Peraturan Pemerintah yang bersifat mandiri, karena tidak ada amanat langsung dalam UU AP untuk ditindaklanjuti dalam Peraturan Pemerintah. Dalam Peraturan dimaksud diatur pula mengenai siapa pejabat yang bisa melakukan diskresi serta lembaga yang dapat memberikan advokasi terkait keterpenuhan syarat;

2. Pada masa transisi, bisa dioptimalkan fungsi Tim Pengawalan, Pengamanan Pemerintahan dan Pembangunan Pusat (TP4P) dan Daerah (TP4D) yang dibentuk oleh Kejaksaan Agung, sebagai lembaga yang dapat memberikan konsultasi dan advokasi bagi aparatur pemerintah, baik pusat maupun daerah, untuk mengambil diskresi;

3. Penguatan peran APIP. APIP semula hanya merupakan "lembaga audit internal biasa" namun sekarang mempunyai kewenangan layaknya "penegak hukum".

4. Perlu dilakukan koordinasi dan sinkronisasi dengan APH, terkait penegakan hukum atas UU AP agar dapat berjalan sebagaimana mestinya. Hal ini dapat dilakukan dalam forum Mahkumjakpol dengan output adalah kesepakatan bersama. Tindaklanjut atas kesepakatan tersebut, Presiden dapat menunjuk Menkopolhukam sebagai koordinator monitoring implementasinya.
5. Dalam rangka menegakkan UU AP, Presiden dapat menginstruksikan kepada Kejaksaan Agung, Kepolisian Negara Republik Indonesia dan BPKP (institusi di ranah eksekutif), untuk melakukan "legal audit" terkait kasus-kasus tindak pidana (pidana umum maupun korupsi), yang menjerat pejabat atau mantan pejabat yang sekarang sedang ditangani di tahap penyelidikan maupun penyidikan. Jika terdapat perkara yang memenuhi persyaratan norma dalam UU AP, maka wajib hukumnya bagi Presiden meminta Kepolisian maupun Kejaksaan agar menyesuaikan dan mentransfer yurisdiksinya ke Pengadilan Tata Usaha Negara (PTUN). Hal ini sesuai dengan Pasal Peralihan UU AP yang pada hakekatnya menyatakan untuk perkara-perkara dalam ranah AP, meskipun sudah didaftarkan di Peradilan Umum, tapi belum masuk pemeriksaan perkara (logikanya apalagi masih tahap penyelidikan atau penyidikan), harus dialihkan penanganannya ke PTUN (bukan Pengadilan Negeri atau Pengadilan Tipikor).

\section{Daftar Pustaka}

\section{Buku}

Atmosudirdjo, S. Prajudi. 1995. Hukum Administrasi Negara. Jakarta: Ghalia Indonesia.

Basah, Sjachran. 1997. Perlindungan Hukum Terhadap Sikap Tindak Administrasi Negara. Bandung: Alumni.

Black, Henry Campbell. 1990. Black's Law Dictionary. West Publishing.

Brouwer J.G dan Schilder. 1998. A Survey of Ductch Administrative Law, Ars Aequi Libri, Nijmegen. 
Hadjon, Philipus M. 2007. Perlindungan Hukum Bagi Rakyat di Indonesia, Sebuah Studi tentang Prinsip-Prinsipnya dan Penanganannya oleh Pengadilan Dalam Lingkungan Peradilan Umum dan Pembentukan Peradilan Administrasi. Cetakan Pertama, Edisi Khusus. Penerbit Peradaban. - Discretionary Power dan Asas-Asas Umum Pemerintahan Yang Baik (AAUPB). 1997. Pengantar Hukum Administrasi Indonesia. Yogyakarta: Gadjah Mada University Press.

Kartawidjaya, Pipit. Kritik Terhadap RUU Administrasi Pemerintahan.

Kobussen, Mariette, De Vrijheid van de Overheid, W.E.J., Tjeenk Willink Zwolle. 1991.

Leyland, Peter and Woods, Terry. 1997. Administrative Law Facing the Future : Old Constraints and New Horizons. London: Blackstone Press Limited.

Marbun, SF. ed. 2001. Pokok-pokok Pemikiran Hukum Administrasi Negara. Yogyakarta: UII Press.

Stroink, F.A.M. en Steenbeek, J.G. 1985. Inleiding in Het Staats-en Administratief Recht. Alphen aan den Rijn Samson: H.D.Tjeenk Willink.

Stout, H.D. 1994. De Betekenissen van de Wet. Zwolle: W.E.J. Tjeenk Willink.

\section{Artikel}

Mustamu, Julista. Diskresi dan Tanggungjawab Administrasi Pemerintahan, SASI (April-Juni 2011):1.

Hoessen, Benyamin. Pembagian Kewenangan Antara Pusat dan Daerah. Arena Hukum: Nomor 13 (Februari 2011).

\section{Peraturan Perundangan}

Undang-Undang Dasar 1945.

Undang-Undang Peradilan Tata Usaha Negara, UU No. 5 Tahun 1986, LN No. 77 Tahun 1986, TLN No. 3344. Undang-Undang Administrasi Pemerintahan, UU No. 30 Tahun 2014, LN No. 292 Tahun 2014, TLN No. 560.

\section{Disertasi/ Tesis /Skripsi}

Marbun, S.F. 2001. Pembentukan, Pemberlakuan, dan Peranan Asasasas Umum Pemerintahan yang Layak dalam Menjelmakan Pemerintahan yang Baik dan Bersih di Indonesia. Disertasi Doktor Universitas Padjadjaran. Bandung.

\section{Informasi Elektronik}

Diskresi Pejabat Sulit Dicari Batasannya, http://www.hukumonline.com. Diakses tanggal 11 maret 2008.

Lumbuun, Gayus T, Pro Kontra Rencana Pembuatan Peraturan untuk Melindungi Pejabat Publik. http://www.hukumonline.com. Diakses tanggal 16 maret 2008. http://setkab.go.id/bertemu-1768pejabat-eselon-ii-presiden-jokowikalau-usul-anggaran-ngga-usahbanyak-banyak/ 